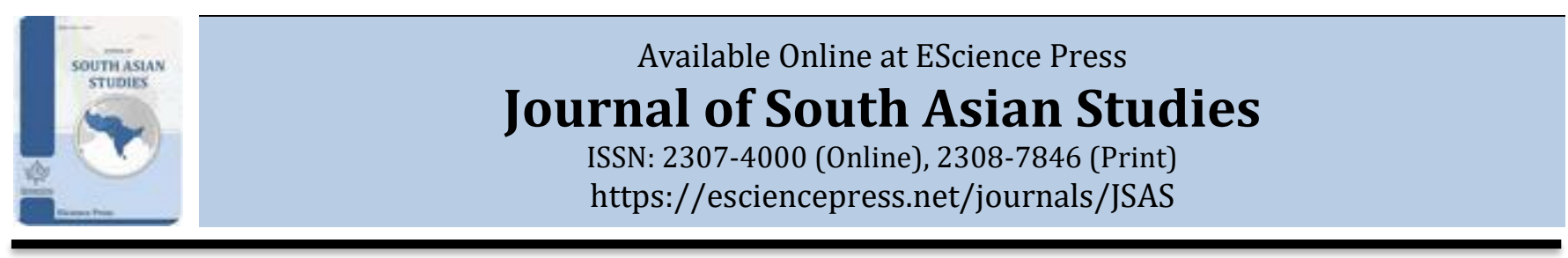

\title{
Trust of Socially Vulnerable Groups on Criminal Justice System of Pakistan
}

\author{
Khalil Ahmad \\ Institute of Social and Cultural Studies, University of the Punjab, Lahore, Pakistan.
}

*Corresponding Author Email ID: khalil.iscs@pu.edu.pk

\begin{abstract}
A B S T R A C T
The present research analyzed the trust of juvenile and women prisoners in the criminal justice system of Pakistan with a focus upon the perceived legitimacy and effectiveness of justice institutions. Data were collected from both under-trial and convicted juvenile and women prisoners of Borstal Institute and District Jail Faisalabad respectively. Although larger proportions of the respondents recognized and accepted the authority of various justice institutions for rule of law, a significant number of respondents viewed that justice institutions protected the interests of powerful people and did not represent moral authority. Larger proportions of respondents did not have trust in procedural fairness of police with regard to respect, impartiality, and fair treatment. However, courts have been trusted for impartiality and fair treatment compared to police and other justice institutions. The logistic results indicated educational attainment, age, prison status, and income level differently influenced experiences of the prisoners towards procedural and distributive fairness of justice institutions. Younger, illiterate, and under-trial prisoners with relatively low household income levels had low perceived legitimacy of justice institutions and less trust in the criminal justice system. Low scoring on socio-economic variables seemed to be related to increased vulnerability of the prisoners, in turn, less trust in the criminal justice system.
\end{abstract}

Keywords: Trust, Justice Institutions, Juveniles, Women prisoners, Perceived legitimacy

\section{INTRODUCTION}

The present research was an attempt to analyze the trust of juvenile and women prisoners in the criminal justice system of Pakistan. In so doing, the perceived legitimacy and effectiveness of justice institutions in administering justice for juvenile and women prisoners were analyzed. The Criminal Justice System (CJS) of Pakistan originates from colonial British rule and comprises three important institutions: Police, Courts, and Prisons (Shinwari, 2015). The CJS aims to control and prevent crime, rehabilitate lawbreakers and provide moral support to the victims. Although many amendments have been made to improve the functioning of all the segments of CJS in Pakistan over the last few decades (Abbas, 2011), socially vulnerable groups are still at the risk of social exclusion (Hameed \& Jamshed, 2013). Wrongful conviction or imprisonment, delayed justice, and use of violence by police lead to a lack of trust among disadvantaged groups (Qayum, Farid,
Shehzad, \& Zhu, 2016).

In Pakistan, the majority of females and juveniles in prison belong to socially and economically vulnerablesegments. They under police custody or in prison suffer through many physical and psychological problems (Ali \& Shah, 2011). Most of them are not aware of their legal rights and lack a support system. Females, at times, had to leave their children or had to live with them in jail andeven sometimes give birth in prison. Almost sixty percent of women in prison have dependent childrenand three percent have to live within jail (Ali \& Shah, 2011). Taking into consideration the social and economic vulnerability of female and juvenile prisoners in Pakistan, it seems crucial to see their level of trust in the justice system of Pakistan. The CJS plays an important role not only in dispensing justice but also keeps the legitimacy of justice institutions intact and ensuring people's commitment to the rule of law. Instilling confidence and trust among socially 
vulnerable groups is believed to play prime role in the collective development and prosperity of societyas a whole. But perceived trust deficit about fair procedural and distributive justice may push socially vulnerable groups to resist all strategies or steps takento improve their lives, which in turn poses serious ramifications for rule of law and protection of legal rights of citizens. A strong base of trust in CJS is important for preventing illegal/wrongful doings and upholding the legitimacy of justice institutions.

\section{BACKGROUND OF THE PROBLEM}

The breakdown of trust in the Criminal Justice System (CJS) remains central to political and social debate (Jackson et al. 2011). Trust in justice, the legitimacy of justice institutions, and people's commitment to the rule of law is cardinal in ensuring the smooth functioning ofthe society. Efficient and capable CJS is a requisite for the implementation of laws in order to provide equality to all social groups in a society according to their civil rights. Police and criminal courts carry out importantfunctions in society and citizens 'outsource' deterrence and justice functions to these institutions, and in return citizens expect them to be fair, impartial, efficient, and effective. Accordingly, trust in justice is the belief that thepolice and criminal courts can be relied upon to act competently, to wield their authority in ways that are procedurally fair and provide equal justice andprotection (Jackson et al. 2011). People's experiences of police, courts, and prisons could be predictors of their trust judgments about procedural and distributive fairness. In other words, the criminal justice system is liable to public trust (Flynn, \& Freiberg, 2018).

Trust and legitimacy are important for public compliance and cooperation with the justice system (Tyler, 1990; 2006; Lind and Tyler, 1988; Sunshine and Tyler, 2003). Trust is also based in part on direct and indirect experiences of criminal justice actors, particularly in relation to their abilities and intentions (Hough, Jackson, Bradford, Myhill, \& Quinton, 2010). Developing a trust system between vulnerablegroups and justice institutions is important because it ensures a peaceful and secure social system for all. Most of the published research focused on citizens'trust and confidence in the criminal justice system. Relatively less attention has been paid to the individuals directly experiencing justice institutions. Procedural and distributive fairness of the criminal justice system can beunderstood and analyzed from the experiences of incarcerated individuals. Surveys carried out from prisoners can be used to measure the efficiency of the justice system and understand recognition and acceptance of legal institutions' right to rule of law. Juvenile and women prisoners' trust in the CJS could help understand the demands and expectations of the vulnerable communities from the state and legislative authorities.

\section{RESEARCH METHODOLOGY}

A quantitative research approach has been adopted to accomplish the current research and a survey design was used for the present research. The interview schedule was used as a tool for data collection. The universe of the present study comprised all eligible and willing inmates (juvenile and women prisoners) of Pakistani origin, irrespective of their age, nature of the crime, and status (under trial or convicted). Data were collected from 36 juvenile and 94 women prisoners from Borstal Institute and District Jail Faisalabad, Faisalabad region of the Province of Punjab, Pakistan. All the SoPs of the Punjab Prisons Department and COVID-19 safety measures were followed in letter and spirit. Informed verbal consent of the inmates was attained, and the researchers were instructed to ensure confidentiality by coding the identity of the respondents.

\section{MAJOR FINDINGS}

Crime and socio-economic profile of juvenile and women prisoners

Socio-economic and psychological factors are significantly associated with crime (Panezai, Wassan, and Saqib, 2019; Ahmed and Murtaza, 2016). Information about the socioeconomic and crime profiles of the respondents was attained and presented in Tables1-2. The data in Table 1 indicate nearly two-thirds (64\%) of the total juvenile were convicted in different types of crime, while 36 percent of the juveniles were under-trial. A larger proportion (69\%) of convicted juvenile prisoners received 4 years and more imprisonment for serious crimes such as murder, rape, and robbery. It is important to note that a little less than one-half of the total juvenile prisoners were repeat offenders and most of them committed theft, robbery, and rape offenses. Juveniles are more likely to face traditional standards of judgment and stigmatization upon their release which may push them to repeat the offense (Ahmed \& Murtaza, 2016). In other words, socio psychological problems resulting from conventional standards and stigmatization could largely be attributed to 
recidivism.

The data indicate that 86 percent of the juvenile were between 16-18 years of age, although the minimum legal age of criminal responsibility is 10 years in Pakistan. Only 14 percent of juvenile prisoners were aged 13-15 - years.
The low educational attainment juveniles could be linked with their age profile. A significant number of juveniles had primary and secondary levels of education. Only 14 percent had intermediate-level education.

Table 1: Profile of Juvenile Prisoners

Name of Prisons: Borstal Institute and Juvenile Prison Faisalabad

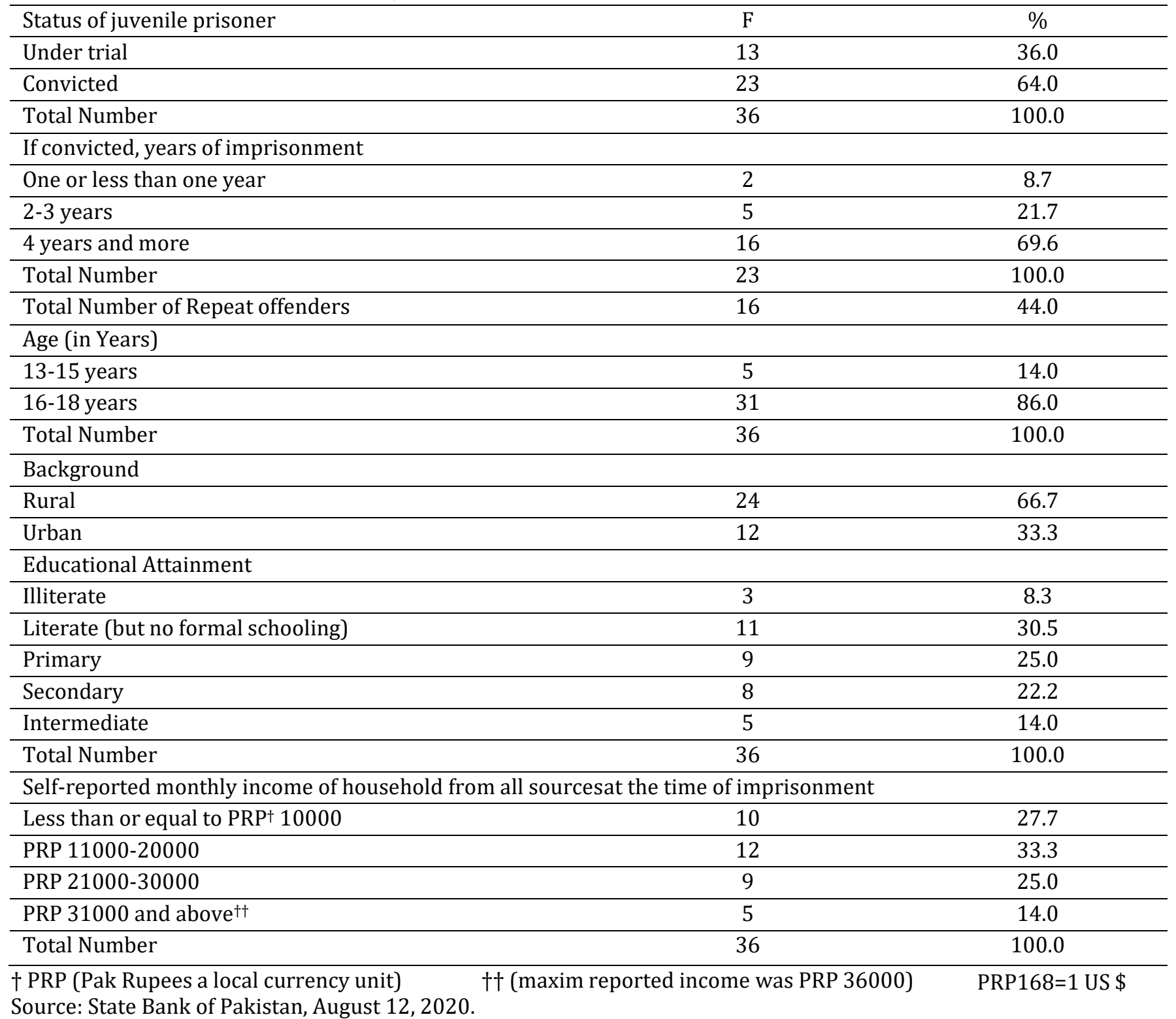

Table 2 provides information about the crime and socioeconomic profile of women prisoners. A little more than one-half (55\%) of the women prisoners were under trial, while 44 percent were convicted. An overwhelming number (95\%) of convicted women prisoners received 4 years and more imprisonment for crimes of murder/attempt to murder, drug-related offense, smuggling, kidnapping, and extramarital relationship. However, fewer women prisoners were charged with crimes of theft, robbery, child trafficking, stealing, and fraud. The data in Table 2 show that more than one-half (54\%) of women prisoners did not receive any formal 
education, while a little more than one-third (36\%) of women had primary and secondary levels of educational attainments and 8 percent reported intermediate level of education. Only 1 respondent had a bachelor's degree. A large proportion $(60 \%)$ of women prisoners were aged 33 years and above, while 35 percent of women prisoners were aged 23-32 years. Only 4 percent were 18-22 years of age. It is important to note that most of the juveniles were from rural areas, while no women prisoners hailed from rural areas. Two things seem to enhance understanding in this regard. First, joint family system/ family support, and second, a crime perpetrated by females in rural areas may not be reported to police to avoid stigma and disgrace in kinship which is relatively stronger in rural areas of Pakistan.

Table 2. Profile of women prisoners.

\begin{tabular}{|c|c|c|}
\hline \multicolumn{3}{|l|}{ Name of Prisons: District/Central Jail Faisalabad } \\
\hline Status of Women Prisoners & F & $\%$ \\
\hline Under trial & 52 & 553 \\
\hline Convicted & 42 & 447 \\
\hline Total Number & 94 & 1000.0 \\
\hline \multicolumn{3}{|l|}{ If convicted, years of imprisonment } \\
\hline One or less than one year & 1 & 2.4 \\
\hline $2-3$ years & 1 & 2.4 \\
\hline 4 years and more & 40 & 95.2 \\
\hline Total Number & 42 & 100.0 \\
\hline Age (in Years) & $\mathrm{F}$ & $\%$ \\
\hline $18-22$ years & 4 & 4.2 \\
\hline 23-27 years & 15 & 16.0 \\
\hline 28-32 years & 18 & 19.0 \\
\hline 33-37 years & 23 & 24.5 \\
\hline 38 years and above & 34 & 36.2 \\
\hline Total Number & 94 & 100.0 \\
\hline \multicolumn{3}{|l|}{ Educational Attainment } \\
\hline Illiterate & 27 & 29.0 \\
\hline Literate (but no formal schooling) & 24 & 25.5 \\
\hline Primary & 18 & 19.0 \\
\hline Secondary & 16 & 17.0 \\
\hline Intermediate & 8 & 8.5 \\
\hline Bachelor & 1 & 1.0 \\
\hline Total Number & 94 & 100.0 \\
\hline \multicolumn{3}{|l|}{ Background } \\
\hline Rural & 0 & 0.0 \\
\hline Urban & 94 & 100.0 \\
\hline Total Number & 94 & 100.0 \\
\hline \multicolumn{3}{|c|}{ Self-reported monthly income of household from allsources at the time of imprisonment } \\
\hline Less than or equal to PRP 10000 & 22 & 23.4 \\
\hline PRP 11000-20000 & 42 & 44.6 \\
\hline PRP 21000-30000 & 20 & 21.3 \\
\hline PRP 31000 and above & 10 & 10.6 \\
\hline Total Number & 94 & 100 \\
\hline
\end{tabular}

Source: The table is made by the author. 
The data in Table 2 show that all women prisoners hailed from urban areas. Overall, a large proportion of women prisoners came from low-income groups withlow literacy levels. Individuals involved in crimes like drug dealing, murder, theft are mostly uneducated, young, and economically underprivileged (Khalid \&Khan, 2013).

\section{PERCEIVED LEGITIMACY OF JUSTICE INSTITUTIONS}

The criminal justice system (CJS) primarily comprises Police, Courts, and Prisons (Shinwari, 2015). Perceived legitimacy of the justice institutions is believed to be important towards the overall trust of individuals in the justice system and their compliance with the legal norms of the society. The data about perceived legitimacy was attained from the respondents to analyze their perceptions about the legal and moral sanctity of justice institutions. Table 3 presents the perceived legitimacy of the justice institutions in terms of the extent of recognition and acceptance of justice institutions for rule of law. The data presented in Table 3 indicate that respondents recognized and accepted courts' right for rule of law followed by prisons and police. Interestingly, a very small percentage of respondents recognized and accepted parliamentarians' right to rule of law. Larger proportions of both juvenile and women prisoners expressed their sense of obligation to obey courts and police. This finding corroborates with (Flynn, \& Freiberg, 2018) that police and courts are seen as legitimate authorities by the public. Although a larger proportion expressed a sense of obligation to obey police and courts, a substantial number of respondents viewed that justice institutions protect the interests of powerful people. Respondents provided an ambivalent response on the question of whether justice institutions represent moral authority or not. A significant number of both juvenile and women prisoners did not believe in the moral authority of justice institutions at all. Overall, larger proportions of both juvenile and women prisoners, to some extent, believed in the moral authority of justice institutions. However, trust is based in part on the direct and indirect experience of criminal justice actors, particularly in relation to their abilities and intentions (Hough, et al., 2010).

Table 3. To what extent do you recognize and accept the right of following for rule of law.

\begin{tabular}{|c|c|c|c|c|c|c|c|c|}
\hline \multirow[t]{2}{*}{ justice institutions } & \multicolumn{2}{|c|}{ e PrisonersN=36 } & \multicolumn{6}{|c|}{ n PrisonersN= 94} \\
\hline & 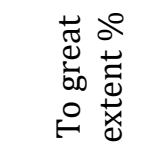 & 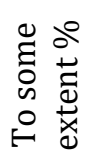 & $\begin{array}{l}\bar{\pi} \\
\stackrel{\pi}{\pi} \\
\stackrel{0}{0} \\
z\end{array}$ & 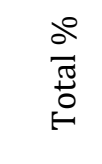 & 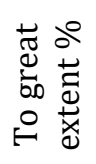 & 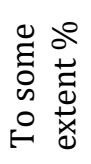 & 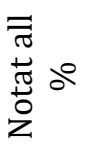 & $\stackrel{\pi}{\stackrel{\pi}{0}} 0^{\circ}$ \\
\hline Parliamentarians & 15 & 20 & 65 & 100.0 & 12 & 19 & 69 & 100.0 \\
\hline Police officials & 40 & 32 & 28 & 100.0 & 32 & 30 & 38 & 100.0 \\
\hline Court officials & 60 & 25 & 15 & 100.0 & 50 & 30 & 20 & 100.0 \\
\hline Prison officials & 55 & 30 & 15 & 100.0 & 40 & 30 & 30 & 100.0 \\
\hline \multicolumn{9}{|l|}{ To what extent do you believe } \\
\hline $\begin{array}{l}\text { in the consent to police authority (asense } \\
\text { of obligation to obey police) }\end{array}$ & 55 & 25 & 20 & 100.0 & 50 & 25 & 25 & 100.0 \\
\hline $\begin{array}{l}\text { in the consent to court authority (a } \\
\text { sense of obligation to obey authorityof } \\
\text { court) }\end{array}$ & 70 & 15 & 15 & 100.0 & 75 & 15 & 10 & 100.0 \\
\hline $\begin{array}{l}\text { Justice system is used to protect the } \\
\text { interests of powerful people }\end{array}$ & 60 & 20 & 20 & 100.0 & 55 & 25 & 20 & 100.0 \\
\hline $\begin{array}{l}\text { Justice institutions (police, courtsand } \\
\text { prisons) represents moral authority }\end{array}$ & 30 & 40 & 30 & 100.0 & 40 & 35 & 25 & 100.0 \\
\hline
\end{tabular}

Source: Table is made by the author.

\section{Trust in justice institutions}

Trust is considered important because it ensures the cooperation between the citizens and justice institutions. Data in Table 4 show that nearly two-thirds of juveniles and a little more than one-half of the women prisoners did not believe at all those police respect the rights of people accused of committing a crime. Nearly one-third of both juvenile and women prisoners were not confident at all those police treat people accused of crime fairly. Similarly, larger proportions of respondents both juvenile and women prisoners did not have trust in police procedural fairness in terms of respect, impartiality, and informing the accused about charges before arrest. Larger proportions of respondents expressed their trust in procedural and distributive fairness of courts 
compared to the police. However, significant numbers of both juvenile and women prisoners believed that courts did provide victims and witnesses with the support/services they need and give sentences that fit the crime. The data show that a significant number of respondents had no confidence at all that prisons reform/rehabilitate prisoners.

Table 4. Trust in Justice Institutions.

Statements

Juvenile Prisoners N=36 Women Prisoners N=94

\begin{tabular}{|c|c|c|c|c|c|c|c|c|}
\hline o what extent are you confident that & 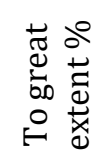 & 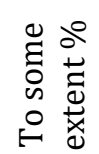 & 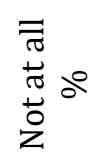 & $\begin{array}{l}\text { ㅇ } \\
\frac{\pi}{0} \\
\stackrel{0}{6}\end{array}$ & 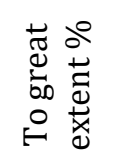 & 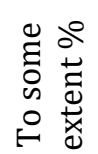 & \begin{tabular}{l}
$\overline{\bar{\sigma}}$ \\
\multirow{0}{\pi}{} \\
$\stackrel{0}{0}$ \\
$z$
\end{tabular} & $\begin{array}{l}\frac{0}{7 \pi} \\
0 \\
0\end{array}$ \\
\hline respects the rights of pe & 10 & 25 & 65 & 100.0 & 15 & 30 & 55 & 100.0 \\
\hline
\end{tabular}

Police respects the rights of people accused of 10 committing a crime

\begin{tabular}{|c|c|c|c|c|c|c|c|c|}
\hline $\begin{array}{l}\text { Police treats people accused of committing a crime } \\
\text { fairly }\end{array}$ & 30 & 40 & 30 & 100.0 & 35 & 30 & 35 & 100.0 \\
\hline Police deals with cases promptly & 25 & 22 & 53 & 100.0 & 22 & 33 & 45 & 100.0 \\
\hline Police arrives quickly at the crime scene & 20 & 25 & 55 & 100.0 & 30 & 30 & 40 & 100.0 \\
\hline $\begin{array}{l}\text { Police makes fair, impartial decisions in the cases } \\
\text { they deal with }\end{array}$ & 25 & 30 & 45 & 100.0 & 20 & 25 & 55 & 100.0 \\
\hline $\begin{array}{l}\text { Police generally informs the accused about } \\
\text { charges before arrest }\end{array}$ & 15 & 30 & 55 & 100.0 & 30 & 40 & 30 & 100.0 \\
\hline Prosecution treats accused people fairly & 30 & 60 & 10 & 100.0 & 40 & 45 & 15 & 100.0 \\
\hline $\begin{array}{l}\text { Courts make fair, impartial decisions } \\
\text { based on the evidence made available to them }\end{array}$ & 55 & 20 & 25 & 100.0 & 50 & 20 & 30 & 100.0 \\
\hline $\begin{array}{l}\text { Courts provide victims of crime with the services } \\
\text { and support they need }\end{array}$ & 25 & 55 & 20 & 100.0 & 40 & 25 & 35 & 100.0 \\
\hline $\begin{array}{l}\text { Courts provide witnesses with the services and } \\
\text { support they need }\end{array}$ & 30 & 30 & 40 & 100.0 & 40 & 30 & 30 & 100.0 \\
\hline $\begin{array}{l}\text { Courts give sentences that fit the crime without } \\
\text { discrimination }\end{array}$ & 45 & 25 & 30 & 100.0 & 40 & 35 & 25 & 100.0 \\
\hline Prisons reform/ rehabilitate prisoners & 20 & 40 & 40 & 100.0 & 30 & 20 & 50 & 100.0 \\
\hline
\end{tabular}

Source: The table is made by the author.

\section{RESULTS}

Logistic regression results in Table 5 show the odds of perceived legitimacy of justice institutions. The findings indicate that women prisoners have higher odds across all the items of perceived legitimacy of justice institutions compared to those of juveniles. Convicts showed greater odds to those of under-trial prisoners. Similarly, prisoners aged 24 years and above had greater odds across all items of perceived legitimacy of justice institutions than those of younger ones. Prisoners with self-reported monthly household income $\geq 31000$ (the US $\$ 194$ at the time of data collection) from all sources indicated increased odds ratios across the statements covered under perceived legitimacy. It may be argued that household income may indirectly influence individuals' experiences with justice institutions. Overall, greater odds with age, literacy, conviction, and self-reported monthly household income of inmates showed greater perceived legitimacy in terms of recognition and acceptance of justice institutions for the rule of law. It may be argued that literate, aged, convicted and prisoners with relatively more household monthly income differently experience the procedural and distributive justice compared to those younger, illiterate, under-trial, and relatively poor prisoners. Perceived negative encounters with law enforcing authorities and less awareness about legal procedures might be responsible for low odds for the recognition and acceptance of legal institutions by younger, under trial, and illiterate prisoners. 
Table 5. Odds Ratios for Factors Associated with Perceived Legitimacy of Justice Institutions.

Perceived legitimacy of Justice Institutions

\begin{tabular}{|c|c|c|c|c|c|c|c|c|}
\hline Variables & $\begin{array}{l}\text { Recognition and } \\
\text { acceptance of } \\
\text { Parliamentarian } \\
\text { s right for rule of } \\
\text { law }\end{array}$ & $\begin{array}{c}\text { Recognition } \\
\text { and acceptance } \\
\text { of Police } \\
\text { officials right } \\
\text { for rule of law }\end{array}$ & $\begin{array}{c}\text { Recognition } \\
\text { and acceptance } \\
\text { of Court } \\
\text { officials right } \\
\text { for rule of law }\end{array}$ & $\begin{array}{c}\text { Recognition } \\
\text { and acceptance } \\
\text { of Prison } \\
\text { officials right } \\
\text { for rule of law }\end{array}$ & $\begin{array}{l}\text { A sense of } \\
\text { obligation to } \\
\text { obey police }\end{array}$ & $\begin{array}{l}\text { A sense of } \\
\text { obligation to } \\
\text { obey authority } \\
\text { of court }\end{array}$ & $\begin{array}{l}\text { Justice system } \\
\text { is used to } \\
\text { protect the } \\
\text { interests of } \\
\text { powerful } \\
\text { people }\end{array}$ & $\begin{array}{c}\text { Justice } \\
\text { institutions } \\
\text { (police, courts } \\
\text { and prisons) } \\
\text { represent } \\
\text { moral authority }\end{array}$ \\
\hline & OR $(95 \% \mathrm{CI})$ & OR $(95 \% \mathrm{CI})$ & OR $(95 \% \mathrm{CI})$ & OR $(95 \% \mathrm{CI})$ & OR $(95 \% \mathrm{CI})$ & OR $(95 \% \mathrm{CI})$ & OR $(95 \% \mathrm{CI})$ & OR $(95 \% \mathrm{CI})$ \\
\hline \multicolumn{9}{|c|}{ Category of prisoner } \\
\hline Juvenile & 1 & 1 & 1 & 1 & 1 & 1 & 1 & 1 \\
\hline Adult Women & $1.5(0.15-1.87)$ & $1.8(0.28-1.09)$ & $1.4(1.2-1.69)$ & $1.76(0.67-2.18)$ & $1.58(0.29-2.08)$ & $1.03(0.37-1.65)$ & $1.39(0.6-2.15)$ & $1.04(0.58-1.55)$ \\
\hline \multicolumn{9}{|c|}{ Status of prisoner } \\
\hline Convicted & 1 & 1 & 1 & 1 & 1 & 1 & 1 & 1 \\
\hline Under-trial & $0.40(0.14-1.32)$ & $0.63(0.3-1.67)$ & $2.3(1.08-3.56)$ & $1.8(0.67-1.98)$ & $0.68(0.34-1.04)$ & $2.9(1.45-3.44)$ & $3.5(2.03-5.3)$ & $0.54(0.9-1.88)$ \\
\hline \multicolumn{9}{|c|}{ Age (in years) } \\
\hline$\leq 18$ & 1 & 1 & 1 & 1 & 1 & 1 & 1 & 1 \\
\hline $19-23$ & $0.58(0.26-1.07)$ & $0.78(1.59-3.2)$ & $0.64(1.04-2.45)$ & $0.63(0.36-1.09)$ & $0.9(1.9-2.3)$ & $0.82(1.66-2.03)$ & $0.67(1.06-2.78)$ & $0.76(1.56-2.89)$ \\
\hline $24-28$ & $1.32(0.35-1.45)$ & $2.5(0.40-2.16)$ & $2.8(0.35-1.79)$ & $1.6(0.75-2.76)$ & $2.67(0.22-1.13)$ & $3.6(0.63-3.37)$ & $2.4(1.07-4.23)$ & $0.81(1.17-1.90)$ \\
\hline $29-33$ & $1.63(0.85-2.34)$ & $2.8(0.70-3.07)$ & $3.4(0.54-4.53)$ & $2.9(1.40-3.45)$ & $2.5(0.16-1.16)$ & $3.2(0.95-2.10)$ & $2.7(0.59-4.32)$ & $0.69(0.88-1.22)$ \\
\hline 34 and above & $2.78(1.5-4.21)$ & $2.6(2.33-4.50)$ & $2.3(1.5-2.77)$ & $3.4(1.9-3.78)$ & $2.68(1.60-3.44)$ & $3.59(0.99-3.62)$ & $3.0(1.8-5.2)$ & $0.83(0.33-1.78)$ \\
\hline \multicolumn{9}{|c|}{ Monthly household income from all sources } \\
\hline$\leq 30000$ & 1 & 1 & 1 & 1 & 1 & 1 & 1 & 1 \\
\hline$\geq 31000$ & $2.45(1.29-4.5)$ & $2.5(1.07-4.23)$ & $3.2(1.95-5.56)$ & $2.7(1.68-4.99)$ & $2.3(1.22-4.78)$ & $3.5(0.98-3.66)$ & $3.1(1.41-3.76)$ & $1.65(0.21-0.68)$ \\
\hline \multicolumn{9}{|l|}{ Education } \\
\hline Illiterate & 1 & 1 & 1 & 1 & 1 & 1 & 1 & 1 \\
\hline Literate & $2.87(1.8-6.7)$ & $2.2(1.30-3.55)$ & $2.9(0.89-3.60)$ & $2.87(1.04-3.90)$ & $2.1(1.20-2.79)$ & $3.7(1.7-4.55)$ & $2.9(1.69-5.21)$ & $0.89(0.55-1.33)$ \\
\hline
\end{tabular}

Logistic regression results in Table 6 show the odds of trust in the criminal justice system. Table 6 shows similar patterns to that of Table 5 for the statementscovered in trust in the criminal justice system of Pakistan. The findings indicate that juvenile, under-trial, younger, illiterate, and prisoners with relatively low household incomes had lower odds, which in turn indicated their lower trust across the statements covered for trust in the criminal justice system compared to those older adults, convicted, literate and prisoners with relatively high household income. The findings emanating from Table 5 and Table 6 imply that younger, illiterate, under-trial prisoners with relatively low household income levels had low perceived legitimacy of justice institutions and less trust in the criminal justice system. Low scoring on socio-economic variables seemed to be related to increased vulnerabilityof the prisoners, in turn, low trust in justice institutions. 
Table 6. Odds Ratios for Factors Associated with Trust in Justice Institutions. Trust in Justice institutions

\begin{tabular}{|c|c|c|c|c|c|c|c|c|c|}
\hline Variables & $\begin{array}{l}\text { Police treats } \\
\text { people } \\
\text { accused of } \\
\text { committing a } \\
\text { crime fairly }\end{array}$ & $\begin{array}{l}\text { Police deals } \\
\text { with cases } \\
\text { promptly }\end{array}$ & $\begin{array}{l}\text { Police treat } \\
\text { people with } \\
\text { respect }\end{array}$ & $\begin{array}{l}\text { Prosecutors } \\
\text { treat all } \\
\text { citizens } \\
\text { equally }\end{array}$ & $\begin{array}{c}\text { Courts make fair, } \\
\text { impartial } \\
\text { decisions based } \\
\text { on the evidence } \\
\text { made available } \\
\text { to them }\end{array}$ & $\begin{array}{l}\text { Courts provide } \\
\text { victims of crime } \\
\text { with the } \\
\text { services and } \\
\text { support they } \\
\text { need }\end{array}$ & $\begin{array}{l}\text { Courts provide } \\
\text { witnesses with the } \\
\text { services and } \\
\text { support they } \\
\text { need }\end{array}$ & $\begin{array}{l}\text { Courts give } \\
\text { sentences that } \\
\text { fit the crime } \\
\text { without } \\
\text { discrimination }\end{array}$ & $\begin{array}{l}\text { Prisons } \\
\text { reform/ } \\
\text { rehabilitate } \\
\text { prisoner s }\end{array}$ \\
\hline & $\overline{\mathrm{AOR}}(95 \% \mathrm{CI})$ & AOR $(95 \%$ & AOR (95\% CI) & AOR $(95 \%$ & AOR (95\% CI) & AOR $(95 \% \mathrm{CI})$ & AOR (95\% CI) & AOR $(95 \% \mathrm{CI})$ & AOR $(95 \% \mathrm{CI})$ \\
\hline
\end{tabular}
CI) $\mathrm{CI})$

\begin{tabular}{|c|c|c|c|c|c|c|c|c|c|}
\hline \multirow{2}{*}{\multicolumn{10}{|c|}{ Category of prisoner }} \\
\hline & & & & & & & & & \\
\hline Adult women & 1 & 1 & 1 & 1 & 1 & 1 & 1 & 1 & 1 \\
\hline Juvenile & $\begin{array}{c}0.6 \\
(0.21- \\
0.67) \\
\end{array}$ & $\begin{array}{c}0.8 \\
(0.22- \\
0.99) \\
\end{array}$ & $\begin{array}{c}0.45 \\
(0.89- \\
1.29) \\
\end{array}$ & $\begin{array}{c}0.76(0 . \\
70- \\
0.69)\end{array}$ & $\begin{array}{c}0.60(0.55- \\
1.76)\end{array}$ & $\begin{array}{c}1.90(0.43 \\
-1.83)\end{array}$ & $\begin{array}{c}0.90 \\
(0.26- \\
1.65) \\
\end{array}$ & $\begin{array}{c}0.04 \\
(0.34- \\
1.66)\end{array}$ & $\begin{array}{r}0.56 \\
(0.55- \\
1.67)\end{array}$ \\
\hline \multicolumn{10}{|c|}{ Status of prisoner } \\
\hline Convicted & 1 & 1 & 1 & 1 & 1 & 1 & 1 & 1 & 1 \\
\hline $\begin{array}{l}\text { Under- } \\
\text { trial }\end{array}$ & $\begin{array}{c}0.78 \\
(0.43- \\
1.56)\end{array}$ & $\begin{array}{c}0.68 \\
(0.33- \\
1.89)\end{array}$ & $\begin{array}{c}0.57 \\
(0.61- \\
1.53)\end{array}$ & $\begin{array}{c}0.89 \\
(0.27- \\
1.56)\end{array}$ & $\begin{array}{c}1.49(0.54- \\
1.66)\end{array}$ & $\begin{array}{c}2.33 \\
(0.99- \\
2.88)\end{array}$ & $\begin{array}{c}0.59 \\
(0.63- \\
1.43)\end{array}$ & $\begin{array}{c}0.54(0.9- \\
1.88)\end{array}$ & $\begin{array}{c}0.76 \\
(0.62- \\
1.50)\end{array}$ \\
\hline \multicolumn{10}{|c|}{ Age (in years) } \\
\hline$\geq 25$ & 1 & 1 & 1 & 1 & 1 & 1 & 1 & 1 & 1 \\
\hline$\leq 24$ & $\begin{array}{c}0.72(0 \\
.22- \\
1.44)\end{array}$ & $\begin{array}{c}0.67 \\
(0.52- \\
1.35)\end{array}$ & $\begin{array}{c}0.79 \\
(0.31- \\
1.27)\end{array}$ & $\begin{array}{c}0.59 \\
(0.25- \\
1.06)\end{array}$ & $\begin{array}{c}0.67(0.34- \\
1.53)\end{array}$ & $\begin{array}{c}0.82 \\
(0.37- \\
1.55)\end{array}$ & $\begin{array}{c}0.56 \\
(0.44- \\
0.99)\end{array}$ & $\begin{array}{c}0.89 \\
(0.63- \\
1.33)\end{array}$ & $\begin{array}{c}0.62 \\
(0.25- \\
1.20)\end{array}$ \\
\hline \multicolumn{10}{|c|}{ Monthly household income from all sources } \\
\hline$\leq 30000$ & 1 & 1 & 1 & 1 & 1 & 1 & 1 & 1 & 1 \\
\hline$\geq 31000$ & $\begin{array}{c}1.72 \\
(0.45- \\
1.98)\end{array}$ & $\begin{array}{c}1.67 \\
(0.35- \\
1.79)\end{array}$ & $\begin{array}{c}1.8 \\
(0.81- \\
2.4)\end{array}$ & $\begin{array}{c}1.67 \\
(0.24- \\
3.63)\end{array}$ & $\begin{array}{l}1.55(1.16- \\
2.69)\end{array}$ & $\begin{array}{l}1.9(0.33- \\
2.13)\end{array}$ & $\begin{array}{c}1.86 \\
(0.49- \\
2.97)\end{array}$ & $\begin{array}{c}1.44 \\
(0.82- \\
2.73) \\
\end{array}$ & $\begin{array}{c}1.63 \\
(0.79- \\
2.33)\end{array}$ \\
\hline \multicolumn{10}{|l|}{ Education } \\
\hline Illiterate & 1 & 1 & 1 & 1 & 1 & 1 & 1 & 1 & 1 \\
\hline Literate & $\begin{array}{c}1.81(0 \\
.8- \\
1.55) \\
\end{array}$ & $\begin{array}{c}1.73 \\
(0.48- \\
1.39) \\
\end{array}$ & $\begin{array}{c}1.82 \\
(0.39- \\
1.57) \\
\end{array}$ & $\begin{array}{c}1.88 \\
(0.66- \\
1.58) \\
\end{array}$ & $\begin{array}{c}1.67(0.98- \\
2.58)\end{array}$ & $\begin{array}{l}1.78(1.4- \\
2.73)\end{array}$ & $\begin{array}{c}1.92 \\
(1.31- \\
2.64) \\
\end{array}$ & $\begin{array}{c}1.86 \\
(1.62- \\
3.44) \\
\end{array}$ & $\begin{array}{c}1.24 \\
(0.68- \\
1.73) \\
\end{array}$ \\
\hline
\end{tabular}

Source: Table made by the author. 


\section{DISCUSSION}

The present study indicated that larger proportions of both juvenile and women prisoners were convicted for serious crimes and received 4 years or more imprisonment. Almost one-half the total juveniles were repeated offenders and most of them committed theft, robbery, and rape offenses. Juveniles face traditional standards of judgment and stigmatization upon their release which may push them to repeat the offense (Ahmed \& Murtaza, 2016). In other words, sociopsychological problems may also result from illiteracy, unemployment, and poor income levels (Ahmed \& Murtaza, 2016; Khan, 2018). Most of the convicted women prisoners committed crimes of murder/attempt to murder, drug-related offenses, smuggling, kidnapping, and extramarital relationship. However, fewer women prisoners were charged with crimes of theft, robbery, child trafficking, stealing, and fraud. Female prisoners reported spousal violence/conflict, poverty, feeling of deprivation, violence by parents-in-law, and neighborhood conflicts among other factors that largely contributed towards their involvement in crimes. Poverty, violence, and illiteracy create the feeling of deprivation, revenge, and anger among socially and economically disadvantaged groups, which in turn contributes to crime (Khalid \& Khan, 2013).

Juvenile and women prisoners are the most vulnerable groups in terms of their relative disadvantageous position. In agreement with Ali \& Shah (2011) low educational attainments, economic dependence, lack of support and lack of awareness about legal rights exacerbate the vulnerability of incarcerated individuals, particularly those who score low on socio-economic variables. Logistic regression results presented in Tables 5 and 6 corroborate this finding. Trust and confidence in terms of procedural and distributive fairness of justice institutions (police, prosecutors, courts, and prisons) remain important in rehabilitating offenders and preventing recidivism. The present study indicated that juvenile and women prisoners had more confidence in courts for equal treatment compared to police, prosecutors, and prisons. However, the promptness and efficiency of the criminal justice system seemed compromised due to the delayed process (Nadeem \& Khan, 2017). In agreement with research (Shabbir, Malik, Hussain, \&Dad, 2018; Ullah, Hussain, Alam \& Akhunzada, 2016), poor performance and partiality of police contributed to low confidence in procedural and distributive fairness of police. Low trust in police efficacy resulted from delayed response to crime scenes and inefficiency of prosecuting criminals (Khan, Shakoor,Aziz, \& Baryal, 2015).

However, it remained instructive to see the relative importance of vulnerability, feeling of discontent, and distrust in justice institutions across gender, age, educational attainments, and household income which might have differential implications for trust or distrust in justice institutions. Logistic regression analysis was conducted towards that effect. The results of logistic regression showed under-trial, younger, illiterate, and low-income inmates had lower odds which indicated their lower trust across the statements covered for perceived legitimacy and trust in the criminal justice system compared to those older adults, convicted, literate prisoners with relatively high household income levels. The logistic results suggest literacy level, age, prison status, and income level differently influence experiences of the prisoners towards procedural and distributive fairness of justice institutions. Perceived negative encounters with law enforcing authorities and less awareness about legal procedures might be responsible for low odds for the recognition and acceptance of legal institutions by younger, under trial, and illiterate prisoners. Low scoring on socio-economic variables was related to increased vulnerability of the prisoners, which in turn resulted in trust deficit.

\section{CONCLUSIONS}

This study concludes that the police is one of the major and primary institutions of CJS with the least level of trust. It may safely be concluded from the findings of the study that police compared to other justice institutions is less effective and efficient. This study concludes that police do not command respect and lacks trust among vulnerable groups, particularly incarcerated juveniles and women. Age, prison status, literacy, and income levels are linked with increased vulnerabilities of prisoners. They may experience differential treatment before and during the investigation, during the trial, and also in prison. It may be concluded that courts command respect and are recognized to ensure rule of law. Courts seem to be recognized for impartial and equal treatment compared to other institutions of the criminal justice system. It may safely be concluded from the findings of this study that reformation and rehabilitation of inmates are not being carried out properly by the prison 
department. Prisoners viewed that vocational training was not skill-based and economically productive.

\section{RECOMMENDATIONS}

Structural and functional changes are needed to improve the efficiency of the police departments through legislative amendments and training programs. Special training programs are needed to enhance the professional behavior of police for gaining the trust of citizens, particularly vulnerable groups. Transparency and accountability of justice institutions are cardinal for procedural and distributive fairness. Skill-based programs are needed for incarcerated juvenile and women prisoners to make them economically productive. Legislative and policy-level interventions are needed to eliminate physical and sexual harassment of women facing justice institutions. Prisons need to initiate programs and activities that promote the psychological, emotional, and physical well-being of incarcerated individuals. The prison department needs to continuously evaluate corrective actions and their utility. In this regard, all stakeholders should be provided with a voice in the process of reformation and rehabilitation of juvenile and women prisoners.

\section{REFERENCES}

Abbas, H. (2011). Reforming Pakistan's police and law enforcement infrastructure. Washington, DC: US Institute of Peace.

Ahmed, U., \& Murtaza, A. (2016). Factors affecting juvenile delinquency in Punjab, Pakistan: a case studyconducted at juvenile prisons in Punjab province. Mediterranean Journal of Social Sciences, 7(4), 372-379.

Ali, A., \& Shah, N. A. (2011). Women prisoners in Pakistan: changing practices to enforce laws and rights. Kuwait Chapter of Arabian Journal of Business and Management Review, 1(4), 57-63.

Avais, M. A., \& Wassan, A. A. (2017). Female criminals, a socio-criminological analysis of Pakistan. Grassroots, 51(1), 110-127.

De Vaus, D., \& de Vaus, D. (2013). Surveys in social research. London: Routledge.

Flynn, A., \& Freiberg, A. (2018). Building trust and confidence in the criminal justice system. In A. Flynn \& A. Freiberg (Eds.), Plea Negotiations Pragmatic Justice in an Imperfect World (pp.207220). Switzerland: Palgrave macmillan.
Hameed, H., \& Jamshed, M. (2013). A study of the criminal law and prosecution system in Pakistan. Manzil Pakistan, 1-32.

Hough, M., Jackson, J., Bradford, B., Myhill, A., \& Quinton, P. (2010). Procedural justice, trust, and institutional legitimacy. Policing: a journal of policy and practice, 4(3), 203-210.

Jackson, J., Hough, M., Bradford, B., Pooler, T., Hohl, K., \& Kuha, J. (2011). Trust in justice: Topline results from the round 5 of the European Social Survey. http://eprints.lse.ac.uk

Khalid, A., \& Khan, N. (2013). Pathways of women prisoners to jail in Pakistan. Health promotion perspectives, 3(1), 31-35.

Khan, A. M., Shakoor, A., Aziz, L., \& Baryal, A. (2015). Factors affecting public trust in police: A study of twin cities (Rawalpindi \& Islamabad). Pakistan Journal of Criminology, 7(4), 89-101.

Khan, I.U., Muhammad, N., Rehman, A.U., and Shah, M.I. (2018). Lack of Exclusive juvenile Prisons: It's Impacton the Well-being of Juvenile Inmates in Khyber Pakhtunkhwa. International Journal of Biology, Pharmacy and Allied Sciences, 7(5), 719731.

Lind, E. A., \& Tyler, T. R. (1988). The social psychology of procedural justice. Springer Science \& Business Media.

Nadeem, M., \& Khan, N. (2017). Paradigm of criminal justice system: Problems and socio-legal reforms in Pakistan. Journal of Law \& Society, XLVIII (71), 63-84.

Panezai, S., Panezai, H., Wassan, A., \& Saqib, S. (2019). Exploring juveniles' delinquent behavior and associated factors: A cross-country comparison of Pakistan and Thailand. Journal of Geography and Social Sciences, 1(1), 57-71.

Qayum, S., Farid, S., Shehzad, S., \& Weidong, Z. (2016). Short comings of criminal justice system of Pakistan and its effects on the rights of accused prisoner wrongfully convicted or imprisoned. Journal of legal studies, 18(32), 13-27.

Shabbir, S. W., Malik, N., Hussain, A., \& Dad, A. (2018). General public perception regarding police department and factors that influence police image inpublic: A case study of district Kasur, Pakistan. Review of Education, Administration \& Law, 1(1), 41-52.

Shinwari, N. A. (2015). Understanding the informal 
justice system: Opportunities and possibilities for pluralism in Pakistan. Accessed at: http://crossasiarepository.ub.uniheidelberg.de/3795/1/Understa ndingtheInformalJusticeSystem.pdf

Sunshine, J., \& Tyler, T. R. (2003). The role of procedural justice and legitimacy in shaping public support for policing. Law \& Society Review, 37(3), 513-548.

Tyler, T. (1990). Why people obey the law. New Haven: Yale University Press. legal

Tyler, T. R. (2006). Why people obey the law. Princeton: Princeton University Press.

Ullah, F., Hussain, S., Alam, H., \& Akhunzada, Z. U. (2016). Factors influencing police image in public (A study of university students perception in KPK Pakistan). Pakistan Journal of Criminology, 8(3), 134- 148.

Funded by: Sustainable Development Policy Institute (SDPI)

Conflict of Interest: The author reports no potentialconflict of interest.

Publisher's note: EScience Press remains neutral with regard to jurisdictional claims in published maps and institutional affiliations.

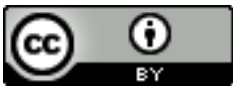

Open Access This article is licensed under a Creative Commons Attribution 4.0 International License, which permits use, sharing, adaptation, distribution and reproduction in any medium or format, as long as you give appropriate credit to the original author(s) and the source, provide a link to the Creative Commons license and indicate if changes were made. The images or other thirdparty material in this article are included in the article's Creative Commons license, unless indicated otherwise in a credit line to the material. If material is not included in the article's Creative Commons license and your intended use is not permitted by statutory regulation or exceeds the permitted use, you will need to obtain permission directly from the copyright holder. To view a copy of this license, visit http://creativecommons.org/licenses/by/4.0/.

(C) The Author(s) 2021. 